\title{
Şahsi Hak Sağlayan Ön Ödemeli Devre Tatil Sözleşmesinde Tüketicinin Sözleşmeden (Serbestçe) Dönme Hakkı
}

\author{
Consumer's Right to Rescission in the Pre-Paid Timeshare Contract \\ Providing Personal Right
}

Mehmet Özgür Avc1 ${ }^{*}$ (iD

\section{öz}

Şahsi hak sağlayan ön ödemeli devre tatil sözleşmesinde tüketicinin baştan ödediği bedeli sermaye olarak kullanan satıcı karşısında taşınmazın kullanılmasını talep etme dışında bir hak elde edemeyen finansör tüketici, satıcıya karşı korunmaya muhtaçtır. Tüketicinin hiçbir gerekçe göstermeksizin kullanabileceği dönme hakkı, tüketicinin korunmasına hizmet eden imkânlardan biridir. Bu hakkın hüküm ve sonuçları tüketici açısından titizlikle incelenmeli ve değerlendirilmelidir.

Anahtar Kelimeler: Tüketici, Şahsi Hak Sağlayan Ön Ödemeli Devre Tatil Sözleşmesi, Dönme Hakkı, Tazminat, İade

\section{ABSTRACT}

The financier consumer, who cannot obtain a right other than demanding the use of the immovable property against the seller who uses the price paid by the consumer as capital in the pre-paid timeshare contract providing personal rights is in need of protection against the seller. The right of rescission, which the consumer can use without any justification, is one of the possibilities that serve to protect the consumer. The terms and consequences of this right should be scrutinized and asses from the consumer point of view.

Keywords: Cunsomer, Pre-Paid Timeshare Contract Providing Personal Right, The Right of Rescission, Compensation, Restitution

\section{Giriş}

6502 sayılı Tüketicinin Korunması Hakkında Kanun (TKHK) m. 50'de ve Devre Tatil ve Uzun Süreli

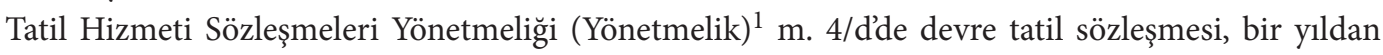
uzun süre için kurulan ve tüketiciye bu süre zarfında birden fazla dönem için bir veya daha fazla sayıda gecelik konaklama imkânı veren sözleşmeler olarak tanımlanmıştır. Bu sözleşmede devre tatil

* $\quad$ Dr. Öğr. Üyesi, Marmara Üniversitesi Hukuk Fakültesi Medeni Hukuk Anabilim Dalı

$1 \quad$ 04.01.2015 tarih, 29236 sayılı Resmi Gazete. "Bu Yönetmeliğin amacı; devre tatil, uzun süreli tatil hizmeti, değişim ve yeniden satış sözleşmelerine uygulanacak usul ve esasları düzenlemektir." (m.1), "Bu Yönetmelik, 07/11/2013 tarihli ve 6502 sayılı Tüketicinin Korunması Hakkında Kanunun 50 ve 84 üncü maddelerine dayanılarak hazırlanmıştır.” (m.3).

Sorumlu Yazar/Correspondence Author: Mehmet Özgür Avc1

E-posta/E-mail: mavci@marmara.edu.tr

Geliş Tarihi/Received: $\quad 01.04 .2021$

Kabul Tarihi/Accepted:

12.05.2021 
satıcıs1/sağlayıcısı ${ }^{1}$ sözleşmede belirtilen dönemlerde konaklamanın yapılacağı yeri tüketiciye teslim etmek ve konaklama boyunca hazır bulundurma borcu altındayken tüketici de toplamı belli olan bir ücret ödeme borcu altındadır.

TKHK'da ön ödemeli devre tatil sözleşmesi tanımlanmamış ancak m. 50'de bu sözleşmeye ilişkin hükümlere yer verilmiştir. Yönetmelik, m. 4/ğ’de ön ödemeli devre tatil sözleşmesi, tüketicinin ayni hakka konu bir taşınmazın satış bedelini veya şahsi hakka konu taşınmazın kullanım hakkı bedelini önceden peşin veya taksitle ödemeyi, satıcının da bedelin tamamen veya kısmen ödenmesinden sonra taşınmazı ya da kullanım hakkını tüketiciye devir veya teslim etmeyi üstlendiği sözleşmeler şeklinde tanımlanmıştır.

Bu tanıma göre, bu sözleşmeyle tüketiciye bir taşınmaz üzerinde ayni ya da şahsi bir hak tanınmakta olup, tüketici tanınan bu hakkın bedelini önceden peşin ya da taksitle ödemeyi, satıcı da bu bedel ödendikten sonra taşınmazı ya da taşınmazın kullanım hakkını devir veya teslim etmeyi taahhüt etmektedir.

TKHK m. 50'nin gerekçesinde de belirtildiği üzere, ön ödemeli konut satışı sözleşmelerinde olduğu gibi devre tatiller de uygulamada maket üzerinden satılabildiğinden hem bu maddede hem de Yönetmelik m. 14-16'da bu sözleşmeye özgü bir takım düzenlemelere yer verilmiştir. Bu sözleşmede tüketici önce sözleşmede kararlaştırılan bedeli ödemekte, daha sonraki bir tarihte ise kendisine tanınan hakka sahip olmaktadır. Ön ödemeli devre tatil sözleşmesinde tüketicinin baştan ödediği bu bedel satıcı açısından sözleşme konusu edimin ifasında sermaye olarak kullanılmaktadır ${ }^{2}$. Tüketicinin baştan ödeme yapmasına rağmen satıcının edimini ifa edememe riskinin varlığ bu sözleşmeye özgü düzenlemeler getirerek tüketici açısından bir takım güvenceler öngörmesine neden olmuştur ${ }^{3}$.

Bu güvencelerden biri de devre tatile konu taşınmazın devir veya teslim tarihine kadar tüketicinin gerekçe göstermeksizin (serbestçe) sözleşmeden dönebilmesidir (TKHK m. 50/f.9, Yönetmelik m. 14/f.3).

Ön ödemeli devre tatil sözleşmesinin tüketiciye taşınmazın kullanım hakkının sağlanması şeklinde kurulması durumunda tüketici, önceden peşin ya da taksitle ödediği bedel karşılığında yılın belirli dönemleri için kararlaştırılan devrelerde, sözleşme konusu taşınmazdan yararlanma hakkı elde etmektedir. Konusu ayni hak olan ön ödemeli devre tatil sözleşmelerinden farklı olarak, burada tüketiciye tanınan kullanım hakkı bir alacak hakkı niteliğindedir. Tüketiciye bir ayni hak

1 Sağlayıcı, kamu tüzel kişileri de dâhil olmak üzere ticari veya mesleki amaçlarla tüketiciye hizmet sunan ya da hizmet sunanın adına ya da hesabına hareket eden gerçek veya tüzel kişiyi ifade eder (TKHK m. 3/1). Kelime tekrarından kaçınmak adına bundan sonra sadece satıcı ifadesi kullanılacaktır.

2 Atamer, Yeșim M., Kredi ve Diğer Finansman Sözleşmelerinde Tüketicinin Korunması, İstanbul 2016, s. 211; Baş Süzel, Ece, Tatil Sözleşmeleri, Devre Tatil, Uzun Süreli Tatil, Değişim, Yeniden Satış Sözleşmeleri ve Paket Tur Sözleşmeleri On İki Levha Yayıncılık, İstanbul 2019, s. 112.

3 Kara, İlhan, 6502 Sayılı Tüketicinin Korunması Hakkında Kanuna Göre Hazırlanmış Tüketici Hukuku, 2. Baskı, Ankara 2021, s. 945. 
tanınmamaktadır ${ }^{4}$. Bu çalışmada şahsi hak sağlayan ön ödemeli devre tatil sözleşmesi ile sınırlı olarak tüketiciye tanınan dönme hakkı ve bu hakkın kullanılmasının sonuçları incelenmiştir.

\section{Dönme Hakkının Hukuki Niteliği}

TKHK m. 50/f.9 ve Yönetmelik m. 14/f.3’e göre, devre tatile konu taşınmazın ön ödemeli satılması durumunda, tüketici devir veya teslim tarihine kadar herhangi bir gerekçe göstermeden sözleşmeden dönebilir. Tüketiciye bu şekilde bir dönme hakkının tanındığı bir diğer düzenleme ise ön ödemeli konut satışlarını düzenleyen TKHK m. 45 hükmüdür. Bu hükme göre, ön ödemeli konut satışında sözleşme tarihinden itibaren yirmi dört aya $\operatorname{kadar}^{5}$ tüketicinin herhangi bir gerekçe göstermeden sözleşmeden dönme hakkı bulunmaktadır ${ }^{6}$.

Bu düzenlemelerde tüketiciye, kanunun ifadesiyle bir dönme hakkı tanınmıştır. Öğretide bir görüşe göre $^{7}$, hukuki bir sebep gösterilmeksizin sözleşmeden dönülebilmesi ancak bu hakkın sözleşme ile kararlaştırılmış olmasına bağlıdır. Sözleşmede bu hak tanınmamışsa bir başka ifadeyle dönme hakkı kanundan kaynaklanıyor ise bu hakkın sebebe bağlı yenilik doğuran bir hak olarak kabul edilmesi gerekir. Sözleşmede kararlaştırılmış olması halinde hiçbir gerekçe gösterilmeksizin dönme hakkının kullanılabilmesi mümkünken taraf iradelerine dayanmayan dönme hakkı kimi durumlarda ahde vefa ilkesinin bir istisnası olarak karşımıza çıkabilir. Taraf menfaatleri dikkate alındığında bu ilkenin sıkı bir şekilde uygulanmasından vazgeçilmesi mümkündür ${ }^{8}$. Özellikle, ekonomik açıdan güçsüz durumda olan tüketicinin bir daha düşünseydi aslında kurmak istemeyeceği bir sözleşmeyi kurması sağlanmış ise ona sözleşme ile bağlı olmaktan kurtulabilme hakkı tanınmalı, bu hak tanınırken hakkın kullanımı sözleşmenin kurulmasından itibaren kısa bir süre ile sınırlandırılmalıdır9 .

4 Çelebi, Funda, Devre Tatil Sözleşmesi, Yayımlanmamış Doktora Tezi, MÜSBE, İstanbul 2006, s. 39-40. Devre tatil alacaklısına dernek üyeliği, şirket ortaklığı tanınarak bir taşınmazdan yararlanma hakkı verilebileceği gibi sadece borç doğuran bir sözleşme ile de devre tatil hakkı verilebilmesi mümkündür., Yağcıŏlu, Burcu, "Periyodik Süreli Tatil Sözleşmeleri”, Dokuz Eylül Üniversitesi Hukuk Fakültesi Dergisi, C. 16, S.1, 2014, s. 203. Şahsi hak sağlayan ön ödemeli devre tatil sözleşmesinde tüketiciye kat irtifakı veya kat mülkiyeti tapusu verilmesi söz konusu değildir., Kara, s. 949. Ayni hak sağlayan devre tatil sistemleri için bkz. Yağcıoğlu, s. 198-203; Koç, Öykü, Türk Hukuku’nda Devre Mülk ve Devre Tatil Sözleșmeleri, Ankara 2021, s. 62-64. Yönetmelik, m. 3’e göre, devre mülk, dönem mülk, paylı mülkiyet, hisseli gayrimenkul satışı ve benzeri isimler altında yapılan ve tapu tesciline konu edilen satışlara ilişkin sözleşmeler, bir yıldan uzun süre için kurulması ve tüketiciye bu süre zarfında birden fazla dönem için bir veya daha fazla sayıda gecelik konaklama imkânı tanıması halinde devre tatil sözleşmesi olarak kabul edilir. Bu maddede belirtilen sözleşmelere konu taşınmazların ön ödemeli satışı, konusu ayni hak olan ön ödemeli devre tatil sözleşmesi olarak nitelendirilmelerine neden olur (Yönetmelik m. 15). Devre tatil sözleşmesi, devre mülk sözleşmesini de kapsamına almakla birlikte, devre tatil ve devre mülk haklarının farkları için bkz. Aslan, İ. Yılmaz, Tüketici Hukuku Dersleri, Güncellenmiş 8. Baskı, Bursa 2021, s. 242.

5 (Değişik: 2/1/2017-KHK-684/8 md.; Aynen kabul: 1/2/2018-7074/8 md.).

6 Devre mülk sözleşmesi açısından da böyle bir sınırlandırmanın yerinde olacağı yönünde bkz. Atamer, s. 244; Baş Süzel, s. 120 .

7 Buz, Vedat, Medeni Hukukta Yenilik Doğuran Haklar, Ankara 2005, s. 209 vd..

8 Saraçoğlu, Simge, “Tüketicinin Korunması Hakkında Kanun Madde 45 Kapsamında Ön Ödemeli Konut Satış Sözleşmesinde Sözleşmeden Dönme ve Dönmeye Bağlanan Tazminat Yaptırımı”, ÇÜHFD, C. 5, S. 1, 2020 , s. 2721.

9 Serozan, Rona, Sözleşmeden Dönme, Gözden Geçirilmiş 2. Bası, İstanbul 2007, s. 369. 
Bu amaca uyun olarak TKHK'da tüketiciye cayma hakkı tanınmıştır. Öğretide, TKHK'da tüketiciye tanınan cayma hakkının bir geri alma hakkı olduğu belirtilmektedir ${ }^{10}$. TKHK m. 50/f.6'da devre tatil sözleşmesi, Yönetmelik m. 7'de de özel olarak ön ödemeli devre tatil sözleşmesi açısından tüketicinin cayma hakkı düzenlenmişken, TKHK m. 50/f.9 ve Yönetmelik m. 14/f.3'de ayrıca dönme hakkına yer verilmiştir.

TKHK m. 45’de de yer alan dönme hakkının hukuki niteliği konusunda öğretide yer alan görüşlerden birine göre ${ }^{11}$, her ne kadar madde lafzında dönme denmişse de sözleşmeden dönme borca aykırılık durumunda ortaya çıkarken cayma hakkında böyle bir durum söz konusu değildir. Burada tüketiciye tanınan bu imkân cayma hakkı niteliğindedir ${ }^{12}$.

Diğer görüş ${ }^{13}$, TKHK m. 45’in gerekçesinde İsviçre Borçlar Kanununun 227. maddesine atıf yapıldığını; bu maddede kanunkoyucunun amacının fesih imkânı tanımak olduğunu; ön ödemeli sözleşmelerde hem tasarruf sözleşmesinin hem de satış sözleşmesinin bulunduğunu, tasarruf sözleşmesinin vekâlet hükümlerinin kıyasen uygulanması gerektiğini ve bu sözleşmenin her zaman sona erdirilmesinin "feshinin" mümkün olduğunu belirterek, dönme hakkından anlaşılması gerekenin fesih olduğuna işaret etmektedir ${ }^{14}$.

Bir başka görüş ${ }^{15}$, bu hakkı keyfi dönme hakkı olarak nitelendirmekte, bu hakkın sözleşmeden dönme niteliği taşıdı̆̆ını belirtmektedir.

Bir diğer görüş ise ${ }^{16}$ TKHK m. 43'de düzenlenen cayma hakkının geri alma hakkı niteliğinde olduğunu; TKHK m. 45'de düzenlenen dönme hakkının bu geri alma hakkının devamı niteliğinde kabul edilmesi gerektiğini ifade etmektedir.

10 Zevkliler, Aydın/Özel, Çağlar, Tüketicinin Korunması Hukuku, Ankara 2016, s. 218; Sirmen, Lale, “Tüketici Hukukunda Taşınmazlarla İlgili Sözleşmeler Bakımından Cayma Hakkı ve Değişken Faize İlişkin Sorunlar”, Tüketici Hukuku Konferansı, 5-6 Aralık 2015, (Editör Hüseyin Can Aksoy), Ankara 2016, s. 388; Akipek Öcal, Şebnem/Öcal, Levent, "Ön Ödemeli Konut Satış Sözleşmesinin Hukuki Niteliği ve Ön Ödemeli Konutların Değerlemesi”, TBB Dergisi, S. 144, 2019, s. 289, dn.13; Ayan, Serkan, "Ön Ödemeli Konut Satış Sözleşmesinde Alıcının Sözleşmeden Cayma Hakkı”, Ankara Hacı Bayram Veli Üniversitesi Hukuk Fakültesi Dergisi, C. 23, S. 3, 2019, s. 57. Geri alma beyanı henüz sözleşmenin kurulmadığı dönemdeki irade beyanın geri alınması anlamında cayma ise kurulmuş olan sözleşmedeki bağlayıcıllı̆̆ sona erdirmek için kullanılmaktadır., Baysal, Başak, "Cayma Hakkının Sözleșme Hukukundaki Yeri, İÜHFM, C. LXXV, S. 1, 2017, s. 274, dn. 2. Tüketiciye tanınan bu hak, sözleşmenin kurulmasına yönelik irade beyanlarının hüküm doğurmasına engel olabileceği gibi hüküm ve sonuçlarıyla ayakta olan bir sözleşmenin çözülmesini de sağlayabilir., Özel, Çağlar, Mukayeseli Hukuk Işığında Tüketiciyi Koruyan Geri Alma Hakkı, Ankara 1999, s. 100. Hüküm ve sonuç doğuran bir iradenin geri alınması durumunda bu geri alma hakkı dönme gibi bir işleve sahiptir., Özel, s. 106.

11 Gümüş, Alper, 6502 Sayılı Tüketicinin Korunması Hakkında Kanun Şerhi, C. 1, (m.1-46), İstanbul 2014, s. 270-271; Makaracı, Aslı, “6502 Sayılı Tüketicinin Korunması Hakkında Kanun Uyarınca Ön Ödemeli Konut Satışı”, Yeni Tüketici Hukuku Konferans1, (Derleyen M. Murat İnceoğlu), İstanbul 2015, s. 258, dn. 28.

12 Aynı yönde Aydoğdu, Murat/Kahveci Nalan, Tüketici Hukuku, Ankara 2021, s. 434; Yağcığlu, s. 236. Tüketiciye tanınan dönme hakkı ikinci bir cayma hakkı olup, bu iki hak arasında sadece tazminat açısından farklılık bulunmaktadır., Çabri, Sezer, Tüketicinin Korunması Hakkında Kanun Şerhi, Ankara 2016, s. 229.

13 Atamer, s. 243.

14 Ani edimli bir sözleşme niteliği taşıyan ön ödemeli konut satışı sözleşmesi için fesih teriminin kullanılmasının yerinde olmadığı, maddedeki iade yükümlülüklerinden tüketicinin sözleşmeden dönme hakkını kullanmasıyla sözleşmenin geçmişe etkili olarak ortadan kalktığının anlaşıldığı görüşü için bkz. Saraçoğlu, s. 2712 - 2713.

15 Özmen, Ethem Saba/Vardar Hamamcıŏlu, Gülşah, 6502 Sayılı Tüketicinin Korunması Hakkında Kanun Uyarınca Ön Ödemeli Konut Satışı Sözleşmeleri, İstanbul 2016, s. 79.

16 Saraçoğlu, s. 2713. 
Ön ödemeli devre tatil sözleşmesinde tüketicinin yaşayabileceği mağduriyetlerin önüne geçilmesi adına tüketiciye hem cayma hakkı hem de sözleşmeden dönme hakkı tanınmıştır. Tüketiciye tanınan dönme hakkı bir geri alma hakkı olarak nitelendirilebilirse de her iki hak açısından farklı esaslar kabul edilmiştir.

Ön ödemeli devre tatil sözleşmelerinde tüketici, sözleşmenin kurulmasından itibaren on dört gün içinde herhangi bir gerekçe göstermeksizin ve cezai şart ödemeksizin cayma hakkını kullanabilir ${ }^{17}$. Cayma hakkı, sözleşmenin kurulmasından itibaren çok sınırlı bir süre içinde kullanılabilir. Cayma hakkını kullanan tüketicinin bir tazminat sorumluluğu yoktur. Bozucu yenilik doğuran bu hakkın kullanılmasıyla ön ödemeli devre tatil sözleşmesi baştan itibaren kesin hükümsüz hale gelir ${ }^{18}$. Sözleşmede bu hakkın kullanılmasının cezai şart ödenmesine bağlı kılınması zorunlu kısmi butlan yaptırımına tabidir ${ }^{19}$.

Satıcı sözleşmeden dönme hakkını sözleşme süresinin sonuna kadar kullanılabilir. Ancak, gerekçe göstermeksizin bu hakkı kullanabilecek olan tüketici kural olarak satıcıya tazminat ödemekle yükümlüdür. Öğretide bir görüşe göre ${ }^{20}$, dönme hakkı on dört günlük cayma süresinin dolmasından sonra doğan bir haktır. Bu sebeple henüz cayma süresi dolmadan önce on dört günlük süre içinde tüketici sözleşmeden döndüğünü beyan etmiş olsa dahi TBK m. 19 uyarınca tüketicinin cayma hakkını kullandığı kabul edilmelidir. Dönme hakkının doğumunun cayma süresine bağlı olmadığı, sözleşmenin yapılmasıyla birlikte bu hakkın doğduğu düşünülse dahi dönme durumunda tüketicin kural olarak tazminat ödemek zorunda kalacak olması, cayma süresi içinde yapılan dönme beyanının tüketici açısından hiçbir yaptırımı olmayan cayma hakkının kullanılması olarak nitelendirilmesini haklı kılar.

\section{Sözleşmenin Geçerli Şekilde Kurulmuş Olması}

Tüketicinin dönme hakkını kullanabilmesi için öncelikle geçerli şekilde kurulmuş bir sözleşmenin varlığ aranır. TKHK m. 50/f.5 ve Yönetmelik m. 6/f.3 uyarınca ön ödemeli devre tatil sözleşmesinin yazılı veya mesafeli satış yöntemiyle kurulabilmesi mümkündür. Yazılı olarak kurulan sözleşmeler açısından geçerlilik şartı olarak nitelikli yazılı şekil şartı aranmıştır ${ }^{21}$. Tüketici kendi el yazısıyla sözleşme tarihini yazmalı ve sözleşmeyi imzalamalıdır. Mesafeli satış yöntemiyle kurulan ön

17 Bu maddede "bu Yönetmelik kapsamında düzenlenen sözleşmelerin..." ifadesine yer verilmek suretiyle, devre tatil, uzun süreli tatili, değişim ve yeniden satıs sözleşmelerinde de tüketicinin cayma hakkı bulunduğuna işaret edilmiştir. Cayma hakkı tüketiciye karmaşık yapıdaki bu sözleşmeleri zaman baskısı olmadan ve psikolojik etki altında kalmadan inceleme fırsatı vermektedir., Çabri, s. 814-815; Baş Süzel, s. 91; Özen, Burak, Editörler Tokbaş, Hakan/Tüzüner, Özlem, Milli Şerh, 6502 Sayılı Tüketicinin Korunması Hakkında Kanun Şerhi, İstanbul 2016, Madde 4, s. 69.

18 Sert Sütçü, Selin, 6502 Sayılı Tüketicinin Korunması Hakkında Kanun Hükümlerine Göre Tüketicinin Cayma Hakkı, Ankara 2016, s. 8; Zevkliler /Özel, s. 218. Cayma hakkının kullanılmasının sözleşmenin kurulmamış sayılmasına neden olacağı görüşü için bkz. Karakocalı, Ahmet/Kurşun, Ali Suphi, Tüketici Hukuku, İstanbul 2015, s. 174.

19 Türk Borçlar Kanunu (TBK) m. 27/f.2 uyarınca şart geçersizken sözleşme ayaktadır., Baş Süzel, s. 101.

20 Çabri, s. 823; Baş Süzel, s. 243.

21 Kara, s. 926; Aydoğdu/Kahveci, s. 428; Yağcıoğlu, s. 218; Çabri, s. 814; Baş Süzel, s. 84; Koç, s. 91. TKHK m. 50/f.5 hükmünde belirtilen şeklin ispata ilişkin bir şart olduğu yönünde bkz. Çınar, Ömer, Editörler Tokbaş, Hakan/Tüzüner, Özlem, Milli Şerh, 6502 Sayılı Tüketicinin Korunması Hakkında Kanun Şerhi, İstanbul 2016, Madde 50, s. 827, dn. 2336. 
ödemeli devre tatil sözleşmelerinde ise nitelikli yazılı şekil şartı aranmamaktadır. Zira bu yöntemle kurulan sözleşmede tüketicinin kendi el yazısıyla sözleşme tarihini yazma ve imzalama olanağ bulunmamaktadır ${ }^{22}$. Ancak, tüketicinin kendi el yazısıyla olmasa da Yönetmelik m. 6/f.1 gereği sözleşme tarihinin mesafeli satış yöntemiyle kurulan ön ödemeli devre tatil sözleşmesinde bulunması zorunludur ${ }^{23}$.

Yönetmelik m. 6/f.1'in son cümlesine göre, sözleşmenin geçersizliğinin ${ }^{24}$ sonradan satıcı tarafından tüketicinin aleyhine olacak şekilde ileri sürebilmesi mümkün değildir. Geçersizlik sadece tüketici tarafından ileri sürülebilir ${ }^{25}$. Hâkim, bu durumu tüketici lehine resen dikkate alabilir ${ }^{26}$.

Tüketicinin dönme beyanını mahkeme yoluyla ileri sürmesi durumunda öncelikle geçerli şekilde yapılmış bir sözleşmenin bulunup bulunmadığı araştırılacaktır. Geçerli şekilde kurulmuş bir sözleşmenin varlığı tespit edilemediği takdirde hâkim şekle aykırılık sebebiyle tarafların verdiklerinin iadesine karar vermelidir.

\section{Dönme Hakkının Kullanılma Şekli}

TKHK m. 50'de dönme hakkının kullanılması herhangi bir şekle bağlı tutulmasa da Yönetmelik m. 14/f.3'de bu beyanın şahsi hakka konu ön ödemeli devre tatil sözleşmeleri için yazılı olarak veya kalıcı veri saklayıcısı ile ayni hakka konu ön ödemeli devre tatil sözleşmeleri için ise noterlikler aracılığıyla satıcıya yöneltilmiş olması gerektiği belirtilmiştir.

Öğretide bir görüşe göre ${ }^{27}$, kanunda dönme hakkının kullanılması için bir şekil öngörülmemişken, ön ödemeli devre tatil sözleşmesinin her iki türü açısından da bu şekilde bir düzenleme getirilmiş olması yerinde olmamıştır. TBK'da da dönme hakkının kullanılması bir şekle bağlanmamışken maddi açıdan zayıf olan tüketiciye masraf yaptırılması, özellikle noter giderlerine katlanmak zorunda bırakılması TKHK’nın amacına ve tüketiciyi koruma düşüncesine aykırılık teşkil eder. Bu sebeple, dönme hakkının kullanılmasına ilişkin bu şekil kuralını ispata ilişkin olarak anlamak ve uygulamak gerekir.

22 Aydoğdu/Kahveci, s. 429; Zevkliler/Özel, s. 348; Yağcıŏlu, 218.

23 Ayni hak sağlayan ön ödemeli devre tatil sözleşmelerinde ise "Daha ağır şekil şartları öngören kanun hükümleri saklıdır." ifadesi gereği resmi şekil şartı aranacaktır., Milli Şerh/Çınar, Madde 50, s. 827-828; Aydoğdu/Kahveci, s. 429; Atamer, s. 227-229.

24 Ön ödemeli devre tatil sözleşmelerine ilişkin ön bilgilendirme formunda (Ek-5) yer alan bilgilerle birlikte tüketicinin adı, soyadı, açık adresi ve diğer iletişim bilgileri ile tarafların sözleşmeyi imzaladığı yer ve tarihe ilişkin bilgiler ön ödemeli devre tatil sözleşmesinin zorunlu içeriğini oluşturur. Sözleşmenin en az on iki punto büyüklügünde, anlaşılabilir bir dilde, açık, sade, okunabilir bir şekilde düzenlenmesi zorunludur. Ayrıca, sözleşmenin bir örneğinin kağıt ortamında veya kalıcı veri saklayıcısı ile tüketiciye verilmesi gerekir (Yönetmelik m. 6). Zorunlu içeriğe riayet edilmemesi, sözleşmenin belirtilen şekilde düzenlenmemesi veya sözleşmenin bir örneğinin verilmemesi, sözleşmenin geçerliliğini etkilemez., Gümüş, s. 36; Milli Şerh/Özen, Madde 4, s. 71 vd.; Aydoğdu/Kahveci, s. 294-295.

25 Karakocalı/Kurşun, s. 172; Kara, s. 925, dn. 20.

26 Baş Süzel, s. 85.

27 Milli Şerh/Çınar, Madde 50, s. 831, dn. 2347. 
Diğer görüş ${ }^{28}$, dönme hakkının şekline ilişkin bu düzenlemenin cayma hakkının kullanılması şekline ilişkin Yönetmelik m. 8/f.1 de öngörülen düzenleme ile aynı olduğunu, tüketicinin hiçbir gerekçe göstermeksizin kullanabileceği bu dönme hakkının TBK’nın genel hükümler bölümünde düzenlenen dönme hakkı olmadığını, bu hakkın tüketiciye tanınan ek bir hak olduğunu ifade etmektedir. Bu durumda bu hakkın kullanılmasının bir şekle bağlanması ve bu şeklin de geçerlilik şekli olarak nitelendirilmesi, bu hakkın kullanılıp kullanılmadığı hususunda tereddütleri ortadan kaldırmak açısından tüketiciye güvence sağlayacaktır. Tüketicinin kendisi açısından çok elverişli olan bu hakkı kullanabilmesi için bazı masraflara katlanacak olması makul görülebilir ${ }^{29}$.

Kanaatimizce kanunda dönme hakkının kullanımına ilişkin bir şekil şartı öngörülmemişken, Yönetmelik ile getirilen şekil şartı geçerlilik şartı olarak kabul edilmemelidir ${ }^{30}$. Tüketici dönme hakkını satıcıya dilediği yöntemle bildirebilmelidir. Tüketici, noter ihtarı, kayıtlı elektronik posta, telefon, faks, iadeli taahhütlü mektup gibi araçlarla bildirimde bulunabilir. Elbette, bu araçların bazıları dönme bildiriminin yapıldığını ispat yükü altında olan tüketici için elverişli olmaz. $\mathrm{Bu}$ sebeple, dönme beyanının yazılı olarak veya kalıcı veri saklayıcısı ile yapılması tüketici açısından ispat kolaylı̆̆ı sağlar ${ }^{31}$.

\section{Dönme Hakkının Teslim Tarihine Kadar Kullanılabilmesi}

Tüketici, dönme beyanını devre tatile konu taşınmazın teslim tarihine kadar satıcıya yöneltebilecektir. Şahsi hakkı konu edinen ön ödemeli devre tatil sözleşmelerinde geçerli bir teslimden bahsedilebilmesi için taşınmazın kullanıma elverişli bir şekilde tüketiciye sunulması gerekir (Yönetmelik m. 16/f.2). Taşınmazın zilyetliğinin devri teslimin gerçekleştiğinin kabulü açısından yeterli değildir. Sözleşme konusu taşınmazın zilyetliği tüketiciye devredilse bile taşınmazın kullanımına engel olan durumların bulunmaması gerekir. Örneğin, taşınmazın elektriği veya suyu yoksa teslimin yapılmadığı kabul edilir ${ }^{32}$.

TKHK m. 50/f.10'da ve Yönetmelik m. 16/f.2'de teslim süresi sınırlandırılmış, teslim için azami bir süre öngörülmüştür. Bu süre sözleşme tarihinden itibaren otuz altı ayı geçemeyecektir. $\mathrm{Bu}$ sinırlandırmayla önceden ödeme yapan tüketicinin hiçbir edim elde edememesi ihtimalinin önüne geçilmek istenmiştir ${ }^{33}$. Sözleşmede kararlaştırılan sürenin otuz altı aydan fazla olması durumunda, dikey kısmi hükümsüzlük yaptırımı sebebiyle sözleşme süresi otuz altı ay olarak kabul edilecektir ${ }^{34}$.

Teslim için sözleşmede kararlaştırılan süre içinde teslim yapılmadıkça tüketici sözleşmeden dönme hakkını kullanabilir. Örneğin, sözleşmenin yapılmasından itibaren otuz altı ay içinde teslimin

28 Baş Süzel, s. 121.

29 Baş Süzel, s. 121.

30 Ön ödemeli konut satışı sözleşmelerinde cayma hakkının kullanılma şekline ilişkin aynı yöndeki görüşler için bkz. Sert Sütçü, s. 105; Özmen/Vardar Hamamcıŏlu, s. 106; Atamer, s. 239; Ayan, s. 67.

31 Kara, s. 947.

32 Kara, s. 949.

33 Aslan, s. 228.

34 Baş Süzel, s. 116. 
gerçekleştirileceği kararlaştırılmış ise tüketici bu azami süre içinde teslim gerçekleşmedikçe her zaman sözleşmeden dönebilir. Ancak, sözleşmede kararlaştırılan bu sürenin dolmasından sonra tüketicinin dönme hakkını kullanabilmesi mümkün değildir. Tüketici genel hükümler çerçevesinde borçlu temerrüdünün sonuçlarından yararlanabilir ${ }^{35}$.

Dönme hakkının kullanılabilmesi teslimin henüz gerçekleşmemiş olması şartına bağlıyken tüketicinin cayma hakkını süresinde kullandığını ispat edememesi durumunda da sözleşme konusu taşınmaz tüketiciye teslim edilmemiş ise tüketici sözleşmeden dönebilir ${ }^{36}$. Hâkim, süresi içinde cayma hakkını kullandığını ispat edemeyen tüketicinin iade talebini bu gerekçeyle reddetmemeli, tüketicinin gerekçe göstermeksizin sözleşmeden dönme hakkına sahip olduğunu dikkate alarak, bu beyanı sözleşmeden dönme olarak nitelendirmeli ve şartları varsa bu talebi kabul etmelidir.

\section{Dönme Hakkını Kullanan Tüketicinin Tazminat Yükümlülüğü}

\section{A. Genel Olarak}

Kanunkoyucu, TKHK m. 50/f.9'da tüketicinin dönme hakkını kullanması durumunda satıcının ondan tazminat talep edebileceğini belirtmiştir. Yönetmelik m. 14/f.4a'da da satıcının bu tazminat hakkına işaret edilmiştir. Tüketicinin sözleşmeden dönmesi durumunda satıcı, sözleşme bedelinin yüzde ikisine kadar tazminat talep edebilecektir. Satıcının talep edebileceği tazminat için bir üst sınır öngörülmüştür.

35 Satıcı sürenin dolmasıyla kendiliğinden (bir ihtara gerek olmaksızın) temerrüde düşer., Milli Şerh/Çınar, s. 832; Karakocalı/Kurşun, s. 176. Otuz altı aylık bu üst sınır, kanundan doğan bir kesin vadedir. Tüketici temerrütten doğan seçimlik haklarını kullanırken mehil vermek zorunda değildir., Baş Süzel, s. 116.

36 Kara, s. 946. Yargıtay vermiş olduğu bir kararda "Mahkemece, 6502 Sayıl Kanun'un 50/6. maddesine göre tüketici devre tatil sözleşmesinden 14 gün içinde herhangi bir gerekçe göstermeksizin ve cezai şart ödemeksizin cayma hakkına sahip olduğu, davacının 22/07/2015 tarihli dilekçesi ile cayma hakkını davalı şirkete bildirdiği her iki tarafın da kabulünde olup, süresinde cayma hakkı kullanılmış olduğundan, davanın kabulüne, taraflar arasında imzalanan 10/07/2015 tarihli ve 100121 Sayll devre tatil üyelik sözleşmesinin iptaline, 5.000,00-TL'nin davalıdan alınarak davacıya verilmesine, sözleşme gereğince davacı tarafından verilen 05/02/2016 ödeme tarihli ve 1.200,00-TL bedelli senedin iptaline, davacı ... açısından geçersiz olduğuna karar verilmiştir. Sözleşmenin imzalandiğı tarihte yürürlükte olan 6502 Sayılı TKHK'nun 50/9. maddesinde, "Devre tatile konu taşınmazın ön ödemeli satılması durumunda, devir veya teslim tarihine kadar tüketicinin herhangi bir gerekçe göstermeden sözleşmeden dönme hakkı vardır.” şeklinde yer alan düzenlemeyle devri ve teslim edilene kadar geçen sürede sözleşmenin askıda olduğu belirtilmiştir. Yine, tüketici teslim ve devir edilene kadar herhangi bir gerekçe göstermeden sözleşmeden dönebilir. Davacının, sözleşmeye uygun kullanımı bulunmadığına ve davacıya söz konusu yerin teslim edildiğine ilişkin bilgi olmadığına göre bu durumda davacının herhangi bir gerekçe göstermeden dönme hakkı bulunduğu değerlendirilerek kabul kararı verilmesi gerekirken mahkemece tebliğ edilip edilmediği belli olmayan 22.07.2015 tarihli yalnızca davacının imzasının bulunduğu yazll belgeye göre süresinde cayma hakkını kullandığı kabul edilerek hatalı gerekçe ile kabul kararı verilmesi usul ve yasaya aykırı olup, bozmayı gerektirir." sonucuna varmıştır., Yarg. 13. HD, E. 2016/25993, K. 2019/12165, T. 5.12.2019, Kazancı İçtihat Bilgi Bankası. Tüketicinin sözleşmenin kurulması sırasında ödemiş olduğu bedelin ve vermiş olduğu senedin iadesi taleplerinin Yönetmelik m. 9/f.1'de düzenlenen "önceden ödeme yapma yasağı" kapsamında değerlendirilmesi ve iadesi gerektiği; kararda belirtilen hükümlere atıf yapılmasına ihtiyaç bulunmadığı, yönünde bkz. Korun, Ceren, "Y. 13. Hukuk Dairesi T. 5.12.201 E. 2016/25993, K. 2019/12165 Sayılı Karar İncelemesi”, Prof. Dr. Ebru Ceylan Tüketici Hukukunda Seçilmiş Yargı Kararları, Ankara 2021, s. 273-280. 
Öğretide bir görüşe göre ${ }^{37}$, satıcıya tanınan bu imkân, satıcının uğramış olduğu zararın tazminine ilişkin olup, bir masraf değildir. Bu bedel, ön bilgilendirme formunda ya da sözleşmede belirtilmemiş olsa dahi satıcı tarafından istenebilir. Satıcının uğradığı zarar yüzde iki oranından daha fazla olsa bile, o bu oran ile yetinmek zorundadır. Zarar, bu oranın altında ise satıcı ancak zararı kadar talepte bulunabilecek, zararı yoksa tazminat talep edemeyecektir.

Diğer görüş̧ ${ }^{38}$, sözleşme bedelinin yüzde ikisi oranındaki tazminat hakkının cezai şart niteliğinde olduğuna ve satıcının zararı olmasa dahi sözleşmede öngörülen bu tutarı (yüzde iki oranını geçmemek kaydıyla) talep edebileceğine işaret etmektedir.

Bir diğer görüş ise $e^{39}$, burada bir dönme cezası bulunduğunu belirtmektedir.

TKHK’nın kabul edilip yürürlüğe girmesinden önce TBMM'ye sunulan ilk metinde TKHK m. 50/f.8,9,10 hükümleri yer almamaktayd1. 26.06.2013 tarihli alt komisyon raporunda "Devre tatile konu olan taşınmazın maketten yapılmak suretiyle ön ödemeye konu edilmesi halinde, ön ödemeli konut satışlarında olduğu gibi burada da teminat ve sözleşmeden dönmeye ilişkin hükümlerin düzenlenmesi faydalı olacağından, devre mülk veya devre tatil satışlarında konutun zamanında teslim edilmemesi halinde tüketicilerin korunması ve sözleşmeden dönme hakkının getirilerek olası tüketici mağduriyetlerinin önlenmesi amacıyla maddeye (7) numaralı fikrasından sonra gelmek üzere üç yeni fikranın (8), (9), (10) numaralı fikralar olarak metne eklenmesi ve diğer fikraların buna göre teselsül ettirilmesine" karar verilmiştir.

Alt Komisyon bu kararı alırken, ön ödemeli konut satışı sözleşmesindeki teminat ve sözleşmeden dönmeye ilişkin hükümleri esas almıştır. Ön ödemeli konut satışını düzenleyen TKHK m. 45 hükmünün gerekçesi şu şekildedir:

"İsviçre Borçlar Kanununun 227/f maddesi örnek alınarak tüketiciye tanınan diğer bir imkân, konutun devir ve teslim edilmesine kadar herhangi bir gerekçe göstermeden sözleşmeden dönme hakkıdır. Kuşkusuz bu hallerde satıcıyı korumak açısından tüketicinin bir dönme cezası ve konutun satışı veya satış vaadi sözleşmesi nedeniyle oluşan vergi, harç ve benzeri yasal yükümlülüklerden doğan masrafları ödemesi sözleşme ile kararlaştırılabilir. Fakat kararlaştırılacak olan dönme cezası en fazla toplam satı̧ bedelinin yüzde ikisi oranında ${ }^{40}$ istenebilecektir".

37 Çabri, s. 824; Baş Süzel, s. 120.

38 Milli Şerh/Çınar, s. 831.

39 Zevkliler/Özel, s. 353.

40 "7/11/2013 tarihli ve 6502 sayılı Tüketicinin Korunması Hakkında Kanunun 45 inci maddesinin birinci fıkrası aşağıdaki şekilde ve aynı maddenin üçüncü fıkrasında yer alan “doksan gün” ibaresi “yüzseksen gün” şeklinde değiştirilmiştir.

"(1) Ön ödemeli konut satışında sözleşme tarihinden itibaren yirmidört aya kadar tüketicinin herhangi bir gerekçe göstermeden sözleşmeden dönme hakkı vardır. Sözleşmeden dönülmesi durumunda satıcı; konutun satışı veya satış vaadi sözleşmesi nedeniyle oluşan vergi, harç ve benzeri yasal yükümlülüklerden doğan masraflar ile sözleşme tarihinden itibaren ilk üç ay için sözleşme bedelinin yüzde ikisine, üç ila altı ay arası için yüzde dördüne, altı ila oniki ay arası için yüzde altısına ve oniki ila yirmidört ay arası için de yüzde sekizine kadar tazminatın ödenmesini isteyebilir.” (2/1/2017KHK-684/8 md., Aynen kabul: 1/2/2018-7074/8 md.). 
Gerekçede satış bedelinin en fazla yüzde ikisi oranındaki bedelin satıcıyı korumak amacıyla tüketicinin ödemesi gereken bir dönme cezası olduğu ve sözleşmede kararlaştırılabileceği belirtilmiştir.

Ön ödemeli devre tatil sözleşmesinde satıcının talep edebileceği bu bedele sözleşmede yer verilmesi gerekip gerekmediği hususunda kanunda ve yönetmelikte bir düzenleme bulunmamaktadır. $\mathrm{Bu}$ konu, TKHK m. 45 kapsamında ön ödemeli satış sözleşmesi açısından öğretide farklı görüşlerin ortaya çıkmasına neden olmuştur. Bir görüşe göre ${ }^{41}$, bu bedelin istenebilmesi ancak sözleşmede kararlaştırılması halinde mümkündür. Çünkü Ön Ödemeli Konut Satışları Hakkında Yönetmelik m. 7/f.1'e göre, sözleşmeden dönme hakkının kullanılma şartları, süresi, usulü ile tazminata ilişkin bilgiler sözleşmenin zorunlu içeriğinde bulunması gereken hususlardır. Diğer görüş ${ }^{42}$, bu bedelin istenebilmesi için sözleşmede kararlaştırılmış olmasını aramamaktadır.

Yönetmelik m. 5 uyarınca sözleşmenin kurulmasından önce tüketiciye verilmesi gereken ön bilgilendirme formunda ön ödemeli devre tatil sözleşmeleri için Ek-5’te yer alan bilgilerin bulunması gerekmektedir.

Ön ödemeli devre tatil sözleşmelerine ilişkin ön bilgilendirme formunda (EK-5) tüketicinin sözleşmeden dönme hakkı ve bu hakka ilişkin bilgiler ile sözleşmeden dönülmesi durumunda, sözleşme bedelinin yüzde ikisine kadar tazminat ödenmesi haricinde tüketiciden herhangi bir isim altında bedel talep edilemeyeceğine ilişkin bilginin yer alması gerekmektedir.

Sözleşmenin esaslı unsuru olmayan ancak Yönetmelik gereği sözleşmenin zorunlu içeriğinde yer alması gereken bu bilgilerin sözleşmede yer almaması sözleşmenin geçerliliğini etkilemeyecek; bu bilgide yer alan hakkın kullanılmasına da engel olmayacaktır ${ }^{43}$. Bu sebeple, satıcı sözleşmede kararlaştırılmamış olsa bile söz konusu bedeli talep edebilecektir. Talep edilebilecek bu bedel için bir üst sınır getirilmiş olduğu için sözleşmede kararlaştırılsın ya da kararlaştırılmasın satıcı bu sınırın üzerinde bir bedel isteyemez.

Kanunkoyucu tüketiciye hiçbir gerekçe göstermeksizin sözleşmeden dönme hakkı tanırken, satıcının uğrayabileceği zararları düşünerek onu korumak adına söz konusu bedelin talep edilebileceğini öngörmüş, böylece tarafların menfaatlerini dengelemeyi amaçlamıştır. TKHK m. 50/f.9 hükmünün lafzına bakıldığında “yüzde ikisine kadar tazminat" ifadesinin kullanıldığı görülmektedir. Alt komisyon kararında ön ödemeli konut satışı sözleşmesine yapılan atıf gereği, ön ödemeli devre tatil sözleşmesinde dönme hakkını kullanan tüketiciden satıcının talep edebileceği bu bedelin hukuki niteliğinin TKHK m. 45 hükmünün gerekçesinde belirtilen dönme cezası olduğu düşünülebilir. Ancak, TKHK m. 45'de bedelin “yüzde ikisi kadar” değil de "yüzde ikisine kadar” denildiği için bu

41 Atamer, s. 244. Ön ödemeli devre tatil sözleşmesinde yüzde ikiyi aşmamak kaydıyla hangi oranda dönme (cayma) tazminatı isteneceğinin kararlaştırılmış olması gerektiği, aksi takdirde satıcının dönme tazminatı talep edemeyeceği yönünde bkz. Aydoğdu/Kahveci, s. 435.

42 Çabri, s. 231; Özmen/Vardar Hamamcıŏglu, s. 92, Doğar, Mehmet, Ön Ödemeli Konut Satışı, Doktora Tezi, KHÜSBE, İstanbul 2017, s. 264.

43 Milli Şerh/Özen, Madde 4, s. 73; Akipek Öcal/Öcal, s. 288-289; Saraçoğlu, s. 2718, dn. 71. 
bedelin tazminat niteliğinde olduğu ve satıcının bu miktara kadar olan zararını ispat etmesi gerektiği de öğretide ifade edilmektedir ${ }^{44}$.

Öğretide bir görüsse göre ${ }^{45}$, bu bedel dönme hakkını kullanan tüketici karşısında zarara uğrayacağı konusunda hemen hemen şüphe bulunmayan satıcının zararının giderilmesi, böylece tarafların menfaatlerinin dengelenmesi amacına yöneliktir. Belli bir miktar ya da oran yerine bir üst sınır öngörülmesi, bu bedelin zararla ilişkilendirildiğini göstermektedir ${ }^{46}$. Bu bedelin sözleşmede kararlaştırılmaması ve satıcının uğradığı zararın üst sınırdan daha az olması durumunda hukuki niteliği, kanun tarafından üst sınırı belirlenen kısmen nispi kanundan doğan bir götürü tazminat olarak kabul edilmelidir. Satıcı üst sınırdan tazminat talep edebilmek için zararın varlığını ispat etmek zorunda değildir. Satıcının bu talebi karşısında tüketici zararın daha az olduğunu ispat ederek daha az tazminata hükmedilmesini sağlayabilir. Söz konusu bedelin sözleşmede belli bir miktar olarak kararlaştırılması durumunda bu bedelin hukuki niteliğinin dönme cezası olarak kabul edilebilmesi mümkündür. Zira bu durumda tüketici kendi iradesine de uygun olarak belirlenen söz konusu bedeli dönme hakkını kullandığı takdirde satıcıya ödeyeceğini kabul etmektedir. Bu bedeli ödeyeceğini kabul eden tüketici satıcının uğramış olduğu zararın daha az olduğu gerekçesiyle söz konusu bedelden daha azına hükmedilmesini sağlayamamalıdır. Kararlaştırılan bu bedel, tarafların bir risk ve menfaat dağılımı yaptıklarını göstermektedir. Satıcı, zararın kararlaştırılan bedelden daha az olması riskini, sözleşmede kararlaştıılan bu bedel sayesinde kanunun dönme hakkı tanıyarak ve zarar için bir üst sınır getirerek koruduğu tüketiciye yükleyebilmelidir.

Dönme cezası, sözleşme taraflarından birinin sözleşmede kendisine tanınan dönme hakkını kullanması durumunda karşı tarafa ödeyeceği bir bedeldir. Kusur ve zarar şartlarından bağımsızdır ${ }^{47}$. Karşı taraf hiçbir zarara uğramamış olsa bile dönme cezasına hak kazanırken, uğramış olduğu zarar ceza tutarından fazla olsa bile ceza tutarı ile karşılanamayan bu zararı (aşkın zarar) için kural olarak tazminat talebinde bulunamaz ${ }^{48}$. Sözleşmede bu talebin saklı tutulabilmesi mümkündür ${ }^{49}$.

44 Öz, Turgut, "Konusu Taşınmaz Olan Tüketici Sözleşmelerinde Geçerlilik ve Borca Aykırılık, Sektörel Bazda Tüketici Hukuku ve Uygulamaları 2014-2015, (Editörler Tokbaş, Hakan/Üçışık, Fehim), Ankara 2015, s. 155.

45 Saraçoğlu, s. 2720-2721.

46 Tazminat sorumluluğu açısından hukuka aykırı bir fiil (borca aykırı davranış) ve tazminat yükümlüsünün kusurunun veya kusursuz sorumluluk hallerinden birinin varlığı aranır. Oysa ki, burada tüketici kanunun kendisine verdiği bir hakkı kullanmakta, borca aykırı bir davranışta bulunmamaktadır. Buna bağlı olarak tüketicinin kusurundan bahsedilebilmesi de mümkün değildir. Ancak, bu durum söz konusu bedelin tazminat olarak nitelendirilmesine engel değildir. TBK m. 512'den hareketle, bu bedel kanun tarafından öngörülen ve sözleşmenin hükümsüz kalması sebebiyle uğranılan menfi zararın tazminine yöneliktir., Saraçoğlu, s. 2720.

47 Kapancı, Berk, "Dönme Cezası (TBK m. 179 f.3) ve Cayma Parası (TBK m. 178) Kavramları Arasında Kısa Bir Karşılaştırma”, MÜHF-HAD, C. 22, S.2, 2016, s. 257. Dönme cezasını ödeyerek sözleşme ilişkisinden kurtulmak isteyen borçlu bu hakka sahip olduğunu ispatlamalıdır. Borçlu bu hakka sahip olduğunu alacaklı ile yaptığı sözleşmeye dayanarak ispatlayabilir., Kılıçoğlu, Ahmet, Borçlar Hukuku Genel Hükümler, Gözden Geçirilmiş-Genişletilmiş 24. Bası, Ankara 2020, s. 992.

48 Tunçomağ, Kenan, Türk Hukukunda Cezai Şart, İstanbul 1963, s. 122; Eren, Fikret, Borçlar Hukuku Genel Hükümler, 25. Baskı, Ankara 2020, s. 1318, N. 3703; Kılıçoğlu, s. 992; Oğuzman, M. Kemal/Öz, Turgut, Borçlar Hukuku Genel Hükümler, Cilt-2, Gözden Geçirilmiş 15. Bası, İstanbul 2020, s. 554, N. 1624. Erdem, Mehmet, "Pey Akçesi - Pişmanlık Akçesi - Dönme Tazminatı", Prof. Dr. Hüseyin Hatemi’ye Armağan, İstanbul 2009, s. 678.

49 Kocaağa, Köksal, Ceza Koşulu (Sözleşme Cezası), Ankara 2018, s. 148; Kapancı, s. 257-258; Erdem, s. 678. 
Dönme cezası, ceza koşulu başlı̆̆ altında TBK m. 179/f.3'de düzenlenmiş olsa da ceza koşulunda esas amaç alacaklının elini güçlendirmek, onun ifa menfaatini güvence altına almaktır. Dönme cezasında ise borçluya ilişkiden sıyrılmak noktasında bir ferahlık sağlanmakta, o bir ceza bedeli ödemek suretiyle sözleşmeden kurtulmaktadır ${ }^{50}$. Öğretide bir görüşe göre, ${ }^{51}$ dönme cezası olarak kararlaştırılan bedelin çok yüksek olduğu ileri sürülerek TBK m. 182/f.3 uyarınca indirilmesi talep edilemez. Ayrıca dönme cezası yerine getirilmesi gereken edimin tutarı açısından belli bir miktarı ifade etmekte olup, alt ve üst sınırlar olmaz ${ }^{52}$.

Tüketicinin sözleşmeden dönme hakkı ve bu hakka ilişkin bilgilerin ön ödemeli devre tatil sözleşmelerine ilişkin ön bilgilendirme formunda (EK-5) yer alması ve bu formun Yönetmelik m. 6 uyarınca ön ödemeli devre tatil sözleşmesinin zorunlu içeriği olması sebebiyle söz konusu bedelin belirlenmemiş olması çok düşük bir ihtimaldir. Ayrıca satıcı, kanunun kendisine verdiği bu hakkı üst sınırdan (yüzde iki) belirlemek isteyecek, satıcının belirlemek istediği oranın aslında bir üst sınır olduğu ve daha düşük bir oran üzerinden bedelin kararlaştırılabileceği bilincinde olmayan birçok tüketici bu oran üzerinden belirlenen bedeli kabul etmek zorunda kalacaktır. Bu şekilde tüketicinin sözleşmeden dönmesi durumunda satıcıya belli bir miktar ödeyeceği kararlaştırılmış ise bu bedelin dönme cezası olarak kabul edilebilmesi mümkündür.

Düşük bir ihtimal olsa da bedelin kararlaştırılmadığı durumlarda "yüzde ikisine kadar" ifadesi kanundan doğan bir götürü tazminat olarak nitelendirilebilecekse de bu durumda zararın varlığını ve miktarını ispat etmekten kurtulan satıcı karşısında satıcının uğradığı zarar miktarının daha az olduğunu ispatlaması neredeyse imkânsız olan tüketici, hâkimin satıcının üst sınırdan talep ettiği bedele hükmetmesine engel olamayacaktır. Bu sebeple, söz konusu bedelin sözleşmede kararlaştırılmış olması ya da olmaması arasında tüketicinin sözleşmeden dönmesi durumunda satıcının elde edeceği bedel açısından çoğu zaman bir farklılık olmayacaktır.

\section{B. Tazminat istenemeyecek Haller}

Satıc1, yükümlülüklerini hiç ya da gereği gibi yerine getirmemiş ise dönme hakkını kullanan tüketici bu bedeli ödemekten kurtulabilir. TKHK m. 50/f.9 ve Yönetmelik m. 14/f.4a’da satıcının yükümlülüklerini hiç ya da gereği gibi yerine getirmezse tüketiciden herhangi bir bedel talep edemeyeceği düzenlenmiş, satıcının yükümlülükleri ifadesinden anlaşılması gerekenin ne olduğuna ilişkin bir açılamaya yer verilmemiştir. Tüketici ile satıcı arasındaki sözleşme ilişkisi dikkate alındığında satıcının sözleşmeden doğan yükümlülüklerini hiç ya da gereği gibi ifa etmemesi söz konusu bedeli talep etmesine engel olacaktır. Ancak, satıcının yükümlülükleri ifadesini sadece

50 Serozan, s. 221; Eren, s. 1316-1317, N. 3698; Kılıçoğlu, s. 991-992; Oğuzman/Öz, s. 550, N. 1610.

51 Tunçomağ, s. 142; Oğuzman/Öz, s. 551, N. 1614; Eren, s. 1319, N. 3706; Erdem, s. 678. Dönme cezasının indirilebileceği yönünde bkz. Serozan, s. 222-228; Tekinay, S. Sulhi/ Akman, Sermet/Burcuoğlu, Haluk/Altop, Atilla, Tekinay Borçlar Hukuku Genel Hükümler, Yeniden Gözden Geçirilmiş ve Genişletilmiş Yedinci Baskı, İstanbul 1993, s. 353. Satıcı üst sınırdan talepte bulunduğunda dönme cezasının indirilebileceği görüşü kabul edilse dahi bu indirim için sadece zararın üst sınırdan daha az olması yeterli olmayacaktır., Saraçoğlu, s. 2721.

52 Kapancı, s. 261; Saraçoğlu, s. 2721. 
sözleşmeden doğan yükümlülükler ile sınırlamak ön ödemeli devre tatil sözleşmesi sebebiyle uygulamada birçok mağduriyet yaşayan tüketiciler açısından isabetli olmayacaktır. Bu sebeple kanunkoyucunun ön ödemeli devre tatil sözleşmesinde tüketiciyi korumak adına bu sözleşmeye özgü olarak satıcı açısından öngörmüş olduğu yükümlülüklerin yerine getirilmemiş olmasının da satıcının tazminata hak kazanmasına engel olacağı kabul edilmelidir.

\section{Sözleşmenin Hiç ya da Gereği Gibi Ifa Edilmemesi}

Satıcının sözleşme konusu edimin ifasında gecikmesi ya da gecikmesinin muhtemel olması ya da ayıplı ifada bulunacağının anlaşıldığı hallerde tüketici satıcıdan herhangi bir bedel talep edemez ${ }^{53}$. Ön ödemeli devre tatil sözleşmesinde teslim süresi sözleşme tarihinden itibaren otuz altı ayı geçemeyecektir. Sözleşmede bir süre kararlaştırılmış ise bu süre sonunda kararlaştırılmamış ise otuz altı ayın sonunda satıcının teslimi gerçekleştiremeyeceği somut durumun şartları çerçevesinde söylenebiliyorsa satıcı tazminat talebinde bulunamaz. Maketten satı̧slarda belirtilen özelliklerin mimari projeye göre teslim ya da devir anında bulunmayacağının anlaşılması da tazminat talebine engeldir.

\section{Satıcının Ek Bilgilendirme Yükümlülügüünü Yerine Getirmemesi}

Yönetmelik m. 14/f.1 uyarınca, şahsi hakka konu taşınmazın kullanım hakkının ön ödemeli satılması durumunda, satıcı tarafından, Ek-5’te yer alan bilgilere ek olarak bağımsız bölüm planı, vaziyet planı, kat planı ve mahal listesinin tüketiciye verilmesi zorunludur. Bu bilgilerin sözleşmenin kurulmasından en az bir gün önce yazılı olarak veya kalıcı veri saklayıcısı ile tüketiciye verilmesi gerekir (Yönetmelik m. 5). Yönetmelik m. 14/f.8, satıcının söz konusu bilgileri tüketiciye verme yükümlülüğünü yerine getirdiğini ispatlaması gerektiğini belirtmiştir. Bu hususu ispatlayamayan satıcı, dönme hakkını kullanan tüketiciden tazminat talep edememelidir.

\section{Yapı Ruhsatının Alınmaması}

Satıcının tüketiciyle ön ödemeli devre tatil sözleşmesi yapmasının ön şartı, sözleşmeye konu taşınmazın inşa edileceği arsa üzerinde yapı ruhsatının alınmış olmasıdır (TKHK m. 50/f.2, Yönetmelik m. 14/f.7). Yapı ruhsatı ile kastedilen inşaatın yapılması için yetkili makamdan alınan izni içeren belgedir (inşaat ruhsatı) ${ }^{54}$. Tüketicinin yaptığı ön ödeme ile finansman sağlayan satıcının özellikle maket üzerinden satış yaparken taşınmazın inşa edileceği arsanın sahibi olmadığı, henüz arsa sahibi ile anlaşmadığ ${ }^{55}$ ya da arsanın makette görüldüğü şekilde inşaat yapımına uygun olmadığı durumlarda sözleşme konusu taşınmazın inşa edilememesi ya da tüketiciye tesliminin

53 Milli Şerh/Çınar, s. 831-832.

54 Aydoğdu/Kahveci, s. 432; Çabri, s. 822; Zevkliler/Özel, s. 351; Baş Süzel, s. 114. İnşaat ruhsatını verecek yetkili makam ilgili belediye veya Çevre Şehircilik Bakanlığıdır.

55 Baş Süzel, s. 114, dn. 347. 
gecikmesi tehlikesi, satıcının sözleşme yapılmadan önce yapı ruhsatı alması şartının getirilmesiyle ortadan kaldırılmak istenmiş, böylece tüketiciye bir koruma sağlanmıştır ${ }^{56}$.

\section{Projede Değişiklik Yapıldığının Bildirilmemesi}

Öğretide, ön ödemeli devre tatil sözleşmesinin eser sözleşmesinden farklı ve karma bir yapıya sahip olması sebebiyle, satıcının tüketicinin onayı olmaksızın proje değişikliği yapabileceği kabul edilmektedir ${ }^{57}$. Bu sözleşmede, TBK m. 470 anlamında tüketici iş sahibi değildir. Proje sahibi inşaatı yapan satıcıdır ${ }^{58}$. Yönetmelik m. 14/f.6 uyarınca, satıcı ön ödemeli devre tatil sözleşmesine konu taşınmazın yer aldığı projede sonradan değişiklik yapması durumunda bu değişikliği tüketiciye yazılı olarak veya kalıcı veri saklayıcısı ile bildirmek zorundadır ${ }^{59}$. Bu bildirimi öngörülen şekilde yapmayan satıcı dönme hakkını kullanan tüketiciden tazminat talebinde bulunamamalıdır.

\section{Sigorta Yapılmaması veya Teminat Verilmemesi}

TKHK m. 50/f.8'e göre, Bakanlıkça belirlenecek büyüklüğün üzerindeki projeler için satıcının ön ödemeli devre tatile konu taşınmazın satışına başlamadan önce bina tamamlama sigortası yaptırması ${ }^{60}$ veya Bakanlıkça belirlenen diğer teminatları sunması gerekmektedir. Projenin büyüklüğü projedeki devre sayısı ya da projenin toplam bedeli kriterlerine göre belirlenir.

Yönetmelik m. 14/f.2'de projenin büyüklüğünü belirleme açısından projenin toplam bedeli kriteri ${ }^{61}$ benimsenmiş ve proje toplam bedelinin bir milyon Türk Lirasını aştığ projeler için, 27/11/2014 tarihli ve 29188 sayılı Resmî Gazete’de yayımlanan Ön Ödemeli Konut Satışları Hakkında

56 Milli Şerh/Çınar, Madde 50, s. 825; Karakocalı/Kurşun, s. 170.; Çabri, s. 822; Aydoğdu/Kahveci, s. 432; Yağcıoğlu, s. 234.

57 Atamer,. s. 248; Gökyayla, Emre, Eser Sözleşmesinde Ek İş ve İş Değişikliği, İstanbul 2009, s. 58 vd..

58 Atamer, s. 248.

59 Bu bildirim üzerine proje değişikliğinden haberdar olan tüketici proje değișikliğini kabul etmiyor ise bildirimin kendisine ulaşmasından itibaren bir ay içinde dönme beyanını satıcıya yöneltmelidir. Bir aylık süre içinde dönme beyanında bulunulması yeterlidir. Beyanın bu süre geçtikten sonra satıcıya ulaşması dönme beyanının hüküm ve sonuç doğurmasına engel olmaz. Dönme beyanı üzerine, satıcı tüketiciden vergi, harç, masraf, tazminat ve benzeri adlar altında hiçbir talepte bulunamaz. Tüketicinin hiçbir bedel ödemeksizin dönem hakkını kullanabilmesi proje değişikliğinin yasal zorunluluklardan veya mücbir sebeplerden kaynaklanmaması hali için söz konusudur. Bir başka anlatımla satıcının iradesine dayalı olarak projede yapılan değişiklikler sebebiyle sözleşmeden dönen tüketici hiçbir bedel ödemeye zorlanamaz. Ancak, değişiklik örneğin, imar mevzuatından kaynaklanan bir sebeple zorunlu olarak yapılmış ise tüketici yine de bu değişikliği kabul etmek zorunda değildir ve bu durumda da dönme hakkını kullanabilir. Ancak bu ihtimalde satıcının sözleşme bedelinin yüzde ikisine kadar kesinti yapabilmesi mümkündür. Yönetmelik m. 14/f.6'da tüketiciye tanınan dönme hakkı, proje değişikliğinin onun tarafından kabul edilmemesi şartına bağlı bir haktır.

60 Bina tamamlama sigortasının kapsamı, koşulları ve uygulama esasları Hazine Müsteşarlığınca belirlenir. Bina tamamlama sigortası kapsamında sağlanan tazminat, teminat ve benzeri güvenceler iflas veya tasfiye masasına dâhil edilemez, haczolunamaz, üzerlerine ihtiyati tedbir ve ihtiyati haciz konulamaz (TKHK m. 50/f.8). Bu sayede verilen güvencelerin tüketiciler için kullanılabilmesi sağlanmıştır., Zevkliler/Özel, s. 352; Baş Süzel, s. 117-118. Satıcıların basiretsiz davranarak ya da bazen de anlaşmalı olarak borç altına girerek, mallarına haciz getirmek suretiyle tüketicileri mağdur etmelerinin önüne geçilmiştir., Aydoğdu/Kahveci, s. 433.

61 Ön Ödemeli Konut Satışları Hakkında Yönetmelik m. 12'de yer alan konut adedi kriteri ön ödemeli devre tatil sözleşmesi açısından uygulanmayacaktır., Milli Şerh/Çınar, Madde 50, s. 831. 
Yönetmeliğin "Teminat" başlıklı beşinci bölümü hükümleri çerçevesinde teminat sağlanması gerektiği belirtilmiştir ${ }^{62}$.

\section{Tarafların Iade Borcu}

Yönetmelik m. 14/4b ve 14/4c'de tarafların iade borcu düzenlenmiştir ${ }^{63}$. Bu hükümler incelendiğinde iade borcunun ifası açısından önceliğin satıcıya verildiği görülmektedir. Satıcı, tüketicinin dönme hakkını kullanması durumunda tüketicinin o ana kadar yapmış olduğu ödeme tutarını ve tüketiciyi borç altına sokan her türlü belgeyi iade etmelidir.

İadenin dönme bildiriminin satıcıya ulaştığı tarihten itibaren en geç doksan gün ${ }^{64}$ içinde yapılması gerekir. Tüketici de alınan bedelin ve kendisini borç altına sokan her türlü belgenin satıcı tarafından kendisine iade edildiği tarihten itibaren on gün içinde kazanımlarını iade edecektir. Satıcı iade konusu edimlerini eksiksiz olarak ifa etmedikçe tüketicinin iade borcu muaccel olmaz.

Satıcının iade borcu, doksan günün geçmesiyle muaccel olur. Muaccel bir borcun borçlusu, kural olarak alacaklının ihtarıyla temerrüde düşer (TBK m. 117/f.1). Ancak, borcun ifa edileceği gün taraflarca belirli vade şeklinde belirlenmiş ise ihtara gerek yoktur. Satıcının iade borcu açısından öngörülen süre, tarafların iradesinden değil Yönetmelikten kaynaklanmaktadır. Bu sebeple, satıcının iade borcunda temerrüde düşmesi tüketicinin ihtarına bağlıdır. Satıcının temerrüdü halinde tüketici kendisine ödenmesi gereken tutarı temerrüt faiziyle birlikte satıcıdan talep edebilir ${ }^{65}$.

Tüketicinin iade borcunda temerrüdünden bahsedebilmek için de ihtar şarttır. Ancakön bilgilendirme formunda (Ek-5) ya da sözleşmede satıcının dönme beyanının kendisine ulaşmasından itibaren doksan gün içinde iade borcunu yerine getirmesi gerektiği, tüketicinin de satıcının iade borcunu tam olarak ifa etmesi üzerine 10 gün içinde kazanımlarını iade edeceği şeklinde bir düzenleme varsa her iki taraf açısından da ihtar şartı aranmaz.

62 Ön Ödemeli Konut Satışları Hakkında Yönetmelik m. 12'de, öngörülen teminat usulleri, kredi teminat mektubu, hakediş sistemi, bağlı kredi ile teminattır. Yönetmelik m. 14-16'da düzenlenen bu usullerle ilgili detaylı açılama için bkz. Atamer, s. 232; Milli Şerh/Çınar, Madde 50, s. 830-831. Satıcının bu yükümlülüğüne aykırı davranışı sözleşmenin geçerliliğini etkilemez, Makaracı, s. 244; Baş Süzel, s. 118. TKHK m. 77/f.8 uyarına satıcıya bir aylık süre verilir. Bu sürede aykırılı̆ıın giderilmemesi halinde idari para cezası uygulanır., bkz. 6502 Sayılı Tüketicinin Korunması Hakkında Kanunun 77. Maddesine Göre 2021 Yllında Uygulanacak Olan İdari Para Cezasına İlişkin Tebliğ, 26.12.2020 tarih, 31346 sayılı RG.

63 Tüketicinin dönme hakkını kullanmasıyla sözleşme ilişkisi baştan itibaren hükümsüz hale geleceğinden taraflar ifa etmiş oldukları edimleri sebepsiz zenginleşme hükümleri çerçevesinde talep edebileceklerdir.

64 Kanunun satıcıya bu şekilde uzun bir süre tanıması yerinde olmamışıı. Cayma hakkına ilişkin on dört günlük sürenin burada da uygulanması gerektiği yönünde bkz. Milli Şerh/Çınar, Madde 50, s. 832.

65 Satıcının tacir olması durumunda TTK m. 3 ve 19 uyarınca tüketicinin avans faizi talep edebilmesi mümkündür. "Davacl, dava dilekçesinde alacağına avans faizi uygulanmasın talep etmiştir. Daval yüklenici tacir olup, taraflardan biri için ticari sayılan iş diğer taraf içinde ticari sayılir. Bu nedenle, mahkemece hükmedilen alacağa avans faizi uygulanması gerekirken, yasal faiz uygulanmış olması usul ve yasaya aykırı olup, bozmayı gerektirir.", Yarg. 13. HD, E. 2019/6303, K. 2019/13140, T. 25.12.2019, Kazancı İçtihat Bilgi Bankası. 
Tüketici satıcıya senet vermiş ise satıcının bu senetleri iade etmesine veya senetler üçüncü kişilerde ise bedelini nakit olarak tüketiciye ödemesine gerek yoktur. Zira, TKHK m. 4/f.5’e göre, tüketicinin yapmış olduğu işlemler nedeniyle kıymetli evrak niteliğinde sadece nama yazılı ve her bir taksit ödemesi için ayrı ayrı olacak şekilde senet düzenlenebilir. Bu hükme aykırı olarak düzenlenen senetler tüketici yönünden geçeriz olacaktır.

Senet, nama düzenlenmiş ise tüketici senedin düzenlenmesine esas olan ön ödemeli devre tatil sözleşmesinden (temel ilişkiden) kaynaklanan savunmaları senedi devralan kişiye karşı da ileri sürebilir ${ }^{66}$. Dönme sebebiyle borcun sona erdiği savunması da bu kapsamda yer alır. Senedin emre yazılı olarak düzenlenmesi durumunda ise anılan hüküm gereği senet tüketici açısından geçersiz olacağından tüketici senet tutarını ödemek zorunda kalmayacaktır.

\section{Dönme Hakkının Kullanılmasının Bağlı Krediye Etkisi}

Ön ödemeli devre tatil sözleşmesinde tüketici sözleşme bedelinin bir kısmını ödemek için kredi kullanabilir. Kullanılan bu kredi bir bağlı kredi ise ${ }^{67}$ Yönetmelik m. 14/f.5 hükmü uygulama alanı bulur. Bu hükümde satıcı ile bağlı kredi veren açısından önce ifa yükümlülüğü öngörülmüştür ${ }^{68}$. Tüketicinin dönme beyanı kendisine ulaşan satıcı, bağlı krediyi verene bu durumu derhal bildirmek zorundadir ${ }^{69}$.

Dönme bildirimini bağlı kredi verene bildirme yükümlülügü altında olan satıcı ayrıca tüketicinin ödediği satış bedelini dönme bildiriminin kendisine ulaştığı tarihten itibaren en geç doksan gün içinde bağlı kredi verene iade etmelidir. Satıcının tüketicinin ödediği satış bedelinden Yönetmelik m. 14/f.4a'da belirtilen tazminat tutarını düşme hakkı bulunmaktadır ${ }^{70}$. Satıcının bağlı kredi verene ödeyeceği tutar, tüketicinin kullandığı kredi tutarı ile sınırlıdır. Örneğin, tüketici sözleşme bedelinin 20.000,00 TL’sini peşin ödemiş geri kalan 10.000,00 TL için kredi kulanmış ise satıcının bağlı kredi verene ödeyeceği tutar 10.000,00 TL'dir. 20.000,00 TL ise tüketiciye iade edilir.

Satıcının iade yükümlülüğünü yerine getirmesinden sonra bağlı kredi veren, tüketicinin o ana kadar yaptığı ödemeleri derhal tüketiciye geri ödeyecektir. Ön ödemeli konut satışı sözleşmesinden dönme

66 Milli Şerh/Özen, Madde 4, s. 107. Devralanın iyiniyet iddiası korunmaz.

67 Bağlı kredi sözleşmesi, tüketici kredisinin münhasıran belirli bir malın veya hizmetin tedarikine ilişkin bir sözleşmenin finansmanı için verildiği ve bu iki sözleşmenin objektif açıdan ekonomik birlik oluşturduğu sözleşmedir. Ekonomik birliğin varlığı, satıcı veya sağlayıcının tüketici için krediyi finanse ettiği; üçüncü bir tarafça finanse edilmesi durumunda, kredi verenin kredi sözleşmesinin imzalanması veya hazırlanması ile ilgili olarak satıcı veya sağlayıcının hizmetlerinden yararlandığı; belirli bir mal veya hizmetin verilmesinin kredi sözleşmesinde açıkça belirtildiği, durumlarından en az birinin varlığı hâlinde kabul edilir (TKHK m. 30).

68 Baş Süzel, s. 122.

69 Tüketici cayma beyanını hem satıcıya hem de bağlı kredi verene bildirmek zorundayken (Yönetmelik m. 11) dönme beyanının satıcıya bildirilmesi yeterlidir. Satıcının bu bildirimi yapmamasının hukuki sonucunun ne olduğu hususunda bir düzenleme bulunmamaktadır. Ön ödemeli konut satışı sözleşmesi açısından bu ihtimalde satıcının bu yükümlülüğüne aykırı davranması sebebiyle tüketicinin uğrayacağı zararı tazmin etmesi gerektiği kabul edilmektedir., Çabri, s. 709; Doğar, s. 273.

70 Alıcının ön ödemeli konut satışı sözleşmesinden dönmesi durumunda satıcı tazminat yanında masrafları da bağlı kredi verene iade edeceği tutardan düşebilir (Ön Ödemeli Konut Satışları Hakkında Yönetmelik m. 9/f.2). 
durumunda TKHK m. 37/f.2 gereği bağlı kredi veren erken ödeme tazminatı kesintisi yapabilirken, burada Yönetmelik m. 14/f.5 hükmünde TKHK m. 27'ye yapılan atıf sebebiyle erken ödeme indirimi yapmak zorundadır. Bağlı kredi veren geri ödemeyi derhal ifa etmez ise tüketicinin ihtarı ile temerrüde düşer. Bu durumda tüketici temerrüt faizi talep edebilir.

Satıcının iade yükümlülüğünü yerine getirmemesi halinde tüketicinin bağlı kredi verene yapmış olduğu ödemeleri ondan talep edebilmesine imkân tanıyan bir düzenleme kanunda ve yönetmelikte bulunmadığı gibi, dönme hakkını kullanan tüketici henüz ödemediği kredi taksitlerini bağlı kredi verene ödemeye devam etmek zorunda kalacaktır. Satıcının iade yükümlülügünü yerine getirmemesinin ortaya çıkardığı bu olumsuz sonuçların önüne geçilebilmesi kanun koyucunun bu konuda bir irade ortaya koyması ile mümkün olabilir.

\section{SONUÇ}

Ön ödemeli devre tatil sözleşmesinde tüketiciye tanınan güvencelerden biri olan dönme hakkı, hukuki olarak bir geri alma hakkı olarak nitelendirilebilirse de hüküm ve sonuçları bakımından tüketiciye tanınan bir diğer hak olan cayma hakkından farklıdır. Her iki hakkın kullanılması açısından tüketicinin bir gerekçe göstermesi aranmazken, dönme hakkını kullanan tüketici kural olarak tazminat ödemekle yükümlüdür. Dönme hakkının on dört günlük cayma süresinin dolmasından sonra doğduğunun kabul edilmesi, bu süre içinde dönme hakkını kullandığını beyan eden tüketicinin bu beyanının cayma olarak nitelendirilmesiyle tüketiciyi tazminat ödeme yükümlülüğünden kurtarır.

Tüketicinin dönme beyanını mahkeme yoluyla ileri sürmesi durumunda hâkim öncelikle geçerli bir sözleşmenin bulunup bulunmadığını tespit etmelidir. Geçerli şekilde kurulmuş bir sözleşme yok ise tüketicinin iade talebinin kabulünün gerekçesi, geçerli bir sözleşmenin bulunmaması olmalıdır. Dönme hakkının kullanılabilmesi ve buna bağlı olarak iade talebinin kabul edilebilmesi için geçerli bir sözleşmenin varlığı aranır.

TKHK'da dönme hakkının kullanımına ilişkin bir şekil şartı öngörülmediği için Yönetmelik ile getirilen şekil şartı geçerlilik şartı olarak kabul edilmemelidir. Tüketici dönme hakkını satıcıya dilediği yöntemle bildirebilir. Ancak bu beyanının yazılı olarak veya kalıcı veri saklayıcısı ile yapılması tüketici açısından ispat kolaylığı sağlar.

Tüketici, dönme hakkını teslim tarihine kadar kullanabilir. Sözleşmede teslim tarihi en fazla otuz altı ay olarak kararlaştırılabilir. Sözleşmede kararlaştırılan sürenin dolmasından sonra tüketicinin dönme hakkını kullanabilmesi mümkün değildir. Bu durumda tüketici genel hükümler çerçevesinde borçlu temerrüdünün sonuçlarından yararlanabilir.

Cayma hakkını süresi içinde kullandığını ispat edemeyen tüketicinin bu hakka dayalı iade talebi, hâkim tarafından bu gerekçeyle reddedilmemeli, tüketicinin teslim tarihine kadar sözleşmeden dönme hakkına sahip olduğu dikkate alınarak, henüz teslim gerçekleşmemiş ise tüketicinin cayma beyanı sözleşmeden dönme olarak nitelendirmeli ve iade talebi şartları varsa kabul edilmelidir. 
Dönme hakkını kullanan tüketici kural olarak sözleşme bedelinin yüzde ikisine kadar tazminat ödemekle yükümlüdür. Bu tazminatın hukuki niteliği konusunda öğretide farklı görüşler bulunmakla birlikte, satıcının her koşulda bu tazminata üst sınırdan hak kazanmak isteyecek olması sebebiyle bu tazminat bedelinin ön ödemeli devre tatil sözleşmesinde kararlaştırılmış olması ile olmaması arasında satıcının elde edeceği bedel açısından çoğu zaman bir farklılık olmayacaktır.

Satıcının yükümlülüklerini hiç ya da gereği gibi yerine getirmemesi tazminat alacağına hak kazanmasına engel olur. Satıcının yükümlülükleri ifadesi sadece sözleşmeden doğan yükümlülükler ile sınırlandırılmamalı, ön ödemeli devre tatil sözleşmesinde tüketiciyi korumak adına bu sözleşmeye özgü olarak satıcı açısından getirilmiş olan diğer yükümlülükleri de yerine getirmeyen satıcı tazminata hak kazanmamalıdır.

Satıcı, dönme hakkını kullanan tüketiciye o ana kadar yapmış olduğu ödeme tutarını ve onu borç altına sokan her türlü belgeyi iade etmelidir. Tüketicinin satıcıya vermiş olduğu senetlerin iade edilmemesi tüketici açısından bir sorun teşkil etmez. Senetler nama düzenlenmişse tüketicinin dönme sebebiyle borcun sona erdiği şeklindeki temel ilişkiden kaynaklanan savunması senedi devralan (iyiniyetli) üçüncü kişilere karşı da sonuç doğurur. Senedin emre yazılı olarak düzenlenmesi ise TKHK m. 4/f.5'e göre tüketici açısından geçersizdir.

Tüketici, sözleşme bedelini ödemek için bağlı krediden faydalanmış ise dönme halinde satıcının iade yükümlülüğünü yerine getirmemesi durumunda tüketicinin bağlı kredi verene yapmış olduğu ödemeleri ondan talep edebilmesine imkân tanıyan bir düzenleme bulunmadığı gibi tüketici henüz ödemediği kredi taksitleri varsa bunları bağlı kredi verene ödemeye devam edecektir. Satıcının iade yükümlülüğünü yerine getirmemesinin ortaya çıkardığı bu olumsuz sonuçlar, kanunkoyucunun bu konuda bir düzenleme yapmasına ihtiyaç bulunduğunu göstermektedir.

\section{KAYNAKÇA}

Akipek Öcal, Şebnem/Öcal, Levent, "Ön Ödemeli Konut Satış Sözleşmesinin Hukuki Niteliği ve Ön Ödemeli Konutların Değerlemesi”, TBB Dergisi, S. 144, 2019, s. 277-298.

Aslan, İ. Yılmaz, Tüketici Hukuku Dersleri, Güncellenmiş 8. Baskı, Bursa 2021.

Atamer, Yeşim M., Kredi ve Diğer Finansman Sözleşmelerinde Tüketicinin Korunması, İstanbul 2016.

Ayan, Serkan, “Ön Ödemeli Konut Satış Sözleşmesinde Alıcının Sözleşmeden Cayma Hakkı”, Ankara Hacı Bayram Veli Üniversitesi Hukuk Fakültesi Dergisi, C. 23, S. 3, 2019, s. 53 - 96.

Aydoğdu, Murat/Kahveci Nalan, Tüketici Hukuku, Ankara 2021.

Baş Süzel, Ece, Tatil Sözleşmeleri, Devre Tatil, Uzun Süreli Tatil, Değişim, Yeniden Satış Sözleşmeleri ve Paket Tur Sözleşmeleri On İki Levha Yayıncılık, İstanbul 2019.

Baysal, Başak, “Cayma Hakkının Sözleşme Hukukundaki Yeri”, İÜHFM C. LXXV, S. 1, 2017, s. 273-292.

Buz, Vedat, Medeni Hukukta Yenilik Doğuran Haklar, Ankara 2005.

Çabri, Sezer, Tüketicinin Korunması Hakkında Kanun Şerhi, Ankara 2016.

Çelebi, Funda, Devre Tatil Sözleşmesi, Yayımlanmamış Doktora Tezi, MÜSBE, İstanbul 2006.

Çınar, Ömer, Editörler Tokbaş, Hakan/Tüzüner, Özlem, Milli Şerh, 6502 Sayılı Tüketicinin Korunması Hakkında Kanun Şerhi, İstanbul 2016 (Milli Şerh/Çınar) 
Doğar, Mehmet, Ön Ödemeli Konut Satışı, Doktora Tezi, KHÜSBE, İstanbul 2017.

Erdem, Mehmet, “Pey Akçesi - Pişmanlık Akçesi - Dönme Tazminatı”, Prof. Dr. Hüseyin Hatemi’ye Armağan, İstanbul 2009, s. 663-684.

Eren, Fikret, Borçlar Hukuku Genel Hükümler, 25. Baskı, Ankara 2020.

Gökyayla, Emre, Eser Sözleşmesinde Ek İş ve İş Değişikliği, İstanbul 2009.

Gümüş, Alper, 6502 Sayılı Tüketicinin Korunması Hakkında Kanun Şerhi, C. 1, (m.1-46), İstanbul 2014.

Kapancı, Berk, "Dönme Cezası (TBK m. 179 f.3) ve Cayma Parası (TBK m. 178) Kavramları Arasında Kısa Bir Karşılaştırma”, MÜHF-HAD, C. 22, S. 2, 2016, s. 247-270.

Kara, İlhan, 6502 Sayılı Tüketicinin Korunması Hakkında Kanuna Göre Hazırlanmış Tüketici Hukuku, 2. Bask1, Ankara 2021.

Karakocalı, Ahmet/Kurşun, Ali Suphi, Tüketici Hukuku, İstanbul 2015.

Kılıçoğlu, Ahmet, Borçlar Hukuku Genel Hükümler, Gözden Geçirilmiş-Genişletilmiş 24. Bası, Ankara 2020.

Kocaağa, Köksal, Ceza Koşulu (Sözleşme Cezası), Ankara 2018.

Koç, Öykü, Türk Hukuku’nda Devre Mülk ve Devre Tatil Sözleşmeleri, Ankara 2021.

Korun, Ceren, "Y. 13. Hukuk Dairesi T. 5.12.201 E. 2016/25993, K. 2019/12165 Sayılı Karar İncelemesi” Prof. Dr. Ebru Ceylan Tüketici Hukukunda Seçilmiş Yargı Kararları, Ankara 2021, s. 273-280.

Makaracı, Aslı, “6502 Sayılı Tüketicinin Korunması Hakkında Kanun Uyarınca Ön Ödemeli Konut Satışı”, Yeni Tüketici Hukuku Konferansı, (Derleyen M. Murat İnceoğlu), İstanbul 2015, s. 241-263.

Oğuzman, M. Kemal/Öz, Turgut, Borçlar Hukuku Genel Hükümler, Cilt-2, Gözden Geçirilmiş 15. Bası, İstanbul 2020.

Öz, Turgut, “Konusu Taşınmaz Olan Tüketici Sözleşmelerinde Geçerlilik ve Borca Aykırılık”, Sektörel Bazda Tüketici Hukuku ve Uygulamaları 2014-2015, Editörler: Tokbaş, Hakan/Üçışık, Fehim, Ankara 2015, s. $138-160$.

Özen, Burak, Editörler Tokbaş, Hakan/Tüzüner, Özlem, Milli Şerh, 6502 Sayılı Tüketicinin Korunması Hakkında Kanun Şerhi, İstanbul 2016 (Milli Şerh/Özen).

Özer, Çağlar, Mukayeseli Hukuk Işığında Tüketiciyi Koruyan Geri Alma Hakkı, Ankara 1999.

Özmen, Ethem Saba/Vardar Hamamcıŏglu, Gülşah, 6502 Sayılı Tüketicinin Korunması Hakkında Kanun Uyarınca Ön Ödemeli Konut Satışı Sözleşmeleri, İstanbul 2016.

Saraçoğlu, Simge, “Tüketicinin Korunması Hakkında Kanun Madde 45 Kapsamında Ön Ödemeli Konut Satış Sözleşmesinde Sözleşmeden Dönme ve Dönmeye Bağlanan Tazminat Yaptırımı”, ÇÜHFD, C. 5, S. 1, 2020, s. 2703-2727.

Serozan, Rona, Sözleşmeden Dönme, Gözden Geçirilmiş 2. Bası, İstanbul 2007.

Sert Sütçü, Selin, 6502 Sayılı Tüketicinin Korunması Hakkında Kanun Hükümlerine Göre Tüketicinin Cayma Hakkı, Ankara 2016.

Sirmen, Lale, “Tüketici Hukukunda Taşınmazlarla İlgili Sözleşmeler Bakımından Cayma Hakkı ve Değiş̧ken Faize İlişkin Sorunlar”, Tüketici Hukuku Konferansı, 5-6 Aralık 2015, (Editör Hüseyin Can Aksoy), Ankara 2016, s. 379-393.

Tekinay, S. Sulhi/ Akman, Sermet/Burcuoğlu, Haluk/Altop, Atilla, Tekinay Borçlar Hukuku Genel Hükümler, Yeniden Gözden Geçirilmiş ve Genişletilmiş Yedinci Baskı, İstanbul 1993.

Tunçomağ, Kenan, Türk Hukukunda Cezai Şart, İstanbul 1963.

Yağcığlu, Burcu, “Periyodik Süreli Tatil Sözleşmeleri”, Dokuz Eylül Üniversitesi Hukuk Fakültesi Dergisi, C. 16, S. 1, 2014, s. 193-250.

Zevkliler, Aydın/Özel, Çağlar, Tüketicinin Korunması Hukuku, Ankara 2016. 